\title{
CRITICAL RACE THEORY AND FEMINIST LEGAL THEORY: PERSPECTIVES ON TRANSFORMATION OF THE JUDICIARY
}

\author{
by Hayley C. Warring*
}

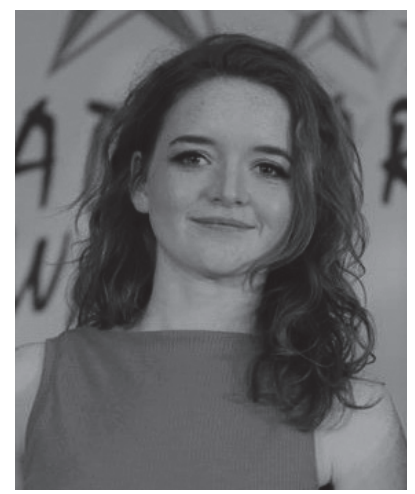

\section{Introduction}

Referring to judicial appointments, Plasket J commented in 2013 that he could see 'no basis on which [the Judicial Service Commission] could refuse to appoint a suitably qualified person' in the presence of qualified white candidates. ${ }^{1}$ He was not alone in this view. Others have suggested that the Judicial Service Commission (JSC) is biased in favour of black and female candidates to the detriment of their white male counterparts. ${ }^{2}$ In this article, I will not endeavour to determine whether this bias in fact exists. The aim of this article is to explore Feminist Legal Theory (FLT) and Critical Race Theory (CRT) perspectives on transformation and the right to equality, with particular attention paid to transformation of the judiciary. This article consists of six parts. In the first section, the historical context

* $\quad$ BCom (Law) (Rhodes University), Final Year LLB Student (Rhodes University). ORCID: 0000-0002-7315-8488.

1 'JSC in Heated Debate Over Transformation' News24 Archives https:// www. news24.com/SouthAfrica/News/JSC-in-heated-debate-over-transformation20130410 (accessed 13 March 2020).

2 N Tolsi 'JSC's Izak Smuts Resigns After Transformation' Mail \& Guardian https:// mg.co.za/article/2013-04-12-izak-smuts-resigns-after-transformation-row/ (accessed 13 March 2020). 
of the JSC's establishment, as well as the standard against which its decisions are measured, is explored. Secondly, the right to equality viewed through the lens of transformative constitutionalism is assessed. The third and fourth segments of this article focus on FLT and CRT respectively. Fifthly, I analyse the commentary from CRT and FLT scholars on human rights and transformative constitutionalism. Finally, I attempt to justify the act of abstention from making appointments in relation to FLT and CRT's notion of refusal.

\section{The JSC, the rule of law and rationality}

The JSC was established in terms of section 178 of the (final) Constitution and is tasked with providing recommendations to the President regarding judicial appointments, conducting public hearings for the appointment of such candidates, and disciplining judges. To better understand the standards against which the JSC's decisions are measured, a brief historical overview of the circumstances leading up to its creation is given below.

Prior to 1994, judges were appointed by the State President, usually at the direction of a cabinet member. The convention was to choose appointees from the ranks of practising senior advocates. ${ }^{3}$ This process of 'executive appointment' did not go unchallenged during constitutional negotiations. The issue was considered by the MultiParty Negotiating Forum (MPNF), which gathered for the first time in April 1993, with 26 participants representing a range of political parties, large and small. ${ }^{4}$ By July, it had agreed on a series of steps towards a new constitution, including adopting constitutional principles against which a later draft would be appraised. ${ }^{5}$

While it made much progress, by April 1994 major sticking points remained, including the issue of judicial appointments. This highly contested issue nearly brought negotiations to a standstill. ${ }^{6}$ Negotiating parties were aware of the power judges would wield under a justiciable constitution. Consequently, some parties sought to achieve democratic control over the judicial appointment process. ${ }^{7}$ The concern with retaining the executive appointment process was that it allowed politics to influence appointments. A government could place political factors over merit when making appointments. ${ }^{8}$ The African National Congress (ANC) and the National Party (NP), both dominant negotiating parties, were eager to depoliticise the

3 I Currie \& J de Waal The new constitutional and administrative law (2002) 301.

4 Constitutional Court of South Africa 'History of the Constitution' https:// www.concourt.org.za/index.php/constitution/history (accessed 21 May 2020).

5 No constitutional principle addressed directly the issue of judicial appointments.

6 Currie \& de Waal (n 3 above) 301.

7 As above.

8 As above. 
appointment process but reluctant to relinquish executive control over it. 9

Parties agreed that the election of judges by popular vote, as is the practice in the United States of America, would not be appropriate. ${ }^{10}$ The Technical Committee proposed that Constitutional Court judges ought to be appointed by Parliament, but this was also rejected. ${ }^{\top 1}$ The option of a committee tasked with judicial appointments, as is the choice in many Commonwealth countries, was eventually agreed on. ${ }^{12}$

This background reveals that the JSC is the product of a political compromise, and this is also evident in its composition. It reflects a 'balance of interests' between politicians, political appointees representing both the executive and legislature - and members of the legal profession. ${ }^{13}$ In terms of the interim Constitution, the JSC was to consist of 17 members. ${ }^{14}$ Just over half of its membership consisted of politicians or political appointees, and the remainder was made up by members of the legal profession. ${ }^{15}$

In the final Constitution, the membership of the JSC was increased to 23 members. The proportion of politicians and political appointees also increased to approximately $65 \% .{ }^{16}$ This composition was challenged upon certification. It was argued that Parliament and the executive were over-represented and that the President had been given too dominant a role in the appointment of judges. ${ }^{17}$ Nevertheless, this composition survived scrutiny against

9 As above.

10 Currie \& de Waal (n 3 above) fn 149.

11 Currie \& de Waal (n 3 above) fn 147.

12 Currie \& de Waal (n 3 above) 302.

13 As above.

14 Section 105(1)IC - (1) There shall be a Judicial Service Commission, which shall, subject to subsection (3), consist of -

(a) the Chief Justice, who shall preside at meetings of the Commission;

(b) the President of the Constitutional Court;

(c) one Judge President designated by the Judges President;

(d) the Minister responsible for the administration of justice or his or her nominee;

(e) two practising advocates designated by the advocates' profession;

(f) two practising attorneys designated by the attorneys' profession;

(g) one professor of law designated by the deans of all the law faculties at South African universities;

(h) four senators designated en bloc by the Senate by resolution adopted by a majority of at least two- thirds of all its members;

(i) four persons, two of whom shall be practising attorneys or advocates, who shall be designated by the President in consultation with the Cabinet;

(j) on the occasion of the consideration of matters specifically relating to a provincial division of the Supreme Court, the Judge President of the relevant division and the Premier of the relevant province.

159 out of 17 members were politicians or political appointees, this is approximately $53 \%$ of its membership.

16 This composition was contained in NT 178(1).

17 Certification of the Constitution of the Republic of South Africa 1996 (4) SA 744 (CC) para 121. 
Constitutional Principles VI and VII, concerning the separation of powers and impartiality of the judiciary respectively, and is now contained in section 178(1)(a)-(j) of the final Constitution of $1996 .{ }^{18}$ The Constitutional Court held that the mere fact that the executive participates in judicial appointments is not inconsistent with the doctrine of separation of powers or the independence of the judiciary. ${ }^{19}$ What is crucial in respect of these Constitutional Principles is that the judiciary functions independently of the legislature and executive, and enforces the law impartially. ${ }^{20}$

It is clear from the proportional representation of politicians and political appointees in the JSC's membership that there is room for political influence in judicial appointments. It is further interesting to note that the Promotion of Administrative Justice Act (PAJA) specifically excludes any of the JSC's decisions from the ambit of strictly reviewable 'administrative action'.21 The reason for this, according to Malan, is that the appointment of judges, specifically those who may review legislative and executive decisions, is in itself political in nature. Accordingly, the government has an interest in excluding it from review in terms of PAJA. ${ }^{22}$ This does not immunise the JSC's decisions from judicial review. The court in Judicial Service Commission $v$ Cape Bar Council noted that its decisions are an exercise of public power, subject to the founding constitutional value of the rule of law and are therefore restrained by the principle of rationality. ${ }^{23}$ The parameters of this restraint are important, given

18 (1) There is a Judicial Service Commission consisting of -

(a) the Chief Justice, who presides at meetings of the Commission;

(b) the President of the Supreme Court of Appeal;

(c) one Judge President designated by the Judges President;

(d) the Cabinet member responsible for the administration of justice, or an alternate designated by that Cabinet member;

(e) two practising advocates nominated from within the advocates' profession to represent the profession as a whole, and appointed by the President;

(f) two practising attorneys nominated from within the attorneys' profession to represent the profession as a whole, and appointed by the President;

(g) one teacher of law designated by teachers of law at South African universities;

(h) six persons designated by the National Assembly from among its members, at

least three of whom must be members of opposition parties represented in the Assembly;

(i) four permanent delegates to the National Council of Provinces designated together by the Council with a supporting vote of at least six provinces;

(j) four persons designated by the President as head of the national executive, after consulting the leaders of all the parties in the National Assembly; and

(k) when considering matters relating to a specific Division of the High Court of South Africa, the Judge President of that Division and the Premier of the province concerned, or an alternate design.

19 Certification case (n 17 above) para 123

20 As above.

21 Section $1(\mathrm{gg})$ Promotion of Administrative Justice Act 3 of 2000.

22 K Malan 'Reassessing judicial independence and impartiality against the backdrop of judicial appointments in South Africa' (2014) 17 Potchefstroom Electronic Law Journal 1969.

2320131 SA 170 (SCA) para 22 
that the Constitution provides little guidance for judicial appointments.

Two direct constitutional mandates of the JSC are relevant to this discussion. The first, contained in section 174(1), sets an absolute criterion for the appointment of judges: '[a]ny appropriately qualified woman or man who is a fit and proper person may be appointed as a judicial officer. ${ }^{24}$ This amounts to a hard rule, non-compliance with which will invalidate the appointment. The second mandate is contained in section 174(2): '[t]he need for the judiciary to reflect broadly the racial and gender composition of South Africa must be considered when judicial officers are appointed.' 25 While section $174(2)$ confers a mandate to the extent that it contains the word 'must', use of the word 'consider' implies a great deal of discretion and flexibility in affording weight to this factor. Consequently, the weight this consideration holds depends on the importance afforded to it by members of the JSC. However, while the JSC enjoys this discretion, it remains bound at all times by the rule of law.

The rule of law is a founding value of our constitutional democracy. ${ }^{26}$ As a restraint on state conduct, it is an evasive and abstract concept, which manifests in practical application as the principle of rationality. ${ }^{27}$ In the Pharmaceutical Manufacturers judgment, it was held that the rule of law requires the non-arbitrary exercise of public power. ${ }^{28}$ This requires that decisions taken must be rationally related to the purpose for which the decision-making power was given. ${ }^{29}$ As such, a decision devoid of the required rational connections, in respect of both its procedural and substantive components, will not survive constitutional scrutiny. ${ }^{30}$

In Judicial Service Commission $v$ Cape Bar Council, the JSC fell afoul of the procedural component of the rationality inquiry. ${ }^{31}$ In response to a request to furnish reasons for its decision to leave vacancies open despite the presence of appropriately qualified white candidates, the JSC did not address what motivated the voting outcome, merely stating that it was the result of the majority's votes. ${ }^{32}$ Our Constitution brought with it 'a culture in which every exercise of power is expected to be justified'. ${ }^{33}$ In light of this, it is

24 Italics for my own emphasis.

25 Italics for my own emphasis.

26 Section 1(c) of the Constitution.

27 Pharmaceutical Manufacturers Association of South Africa and Another: In re Ex Parte President of the Republic of South Africa and Others 20002 SA 674 para 85; Masethla $v$ President of the Republic of South Africa 20081 BCLR 1 (CC) para 179.

28 Pharmaceutical Manufacturers (n 27 above) para 85.

29 Pharmaceutical Manufacturers (n 27 above) para 79.

30 I Currie \& J de Waal The Bill of Rights Handbook (2013) 12.

31 Judicial Service Commission (n 23 above) para 45.

32 Judicial Service Commission (n 23 above) para 38.

33 Etienne Mureinik, 'A Bridge to Where? Introducing the Interim Bill of Rights' (1994) 10 South African Journal on Human Rights 32. 
unsurprising that the court held that the JSC could not be exempted from furnishing reasons for its decision, as this would effectively immunise those decisions from a rationality inquiry. ${ }^{34}$

This article is primarily concerned with the substantive component of the rationality inquiry, in particular how appointments or abstentions from making appointments, which are motivated by the goal of transforming the judiciary may be justified. Nevertheless, the substantive and procedural components are closely entwined. The substance of the reasons given must show a crucial rational connection to a legitimate governmental purpose, and that decision must respect the individual's basic rights. ${ }^{35}$ In this article, I propose that the legitimate governmental purpose must be the furtherance of the constitutional transformative project. The following section considers the nature of transformative constitutionalism and the right to equality in terms of our post-liberal Constitution.

\section{Transformative constitutionalism and the right to equality}

The commitment to transform our society lies at the heart of our constitutional democracy. ${ }^{36}$ Former Deputy Chief Justice Moseneke stated that 'the meaning of transformation in juridical terms is as highly contested as it is difficult to formulate'. 37 The late former Chief Justice Langa considered that perhaps it is in the spirit of transformation that no rigid understanding of the concept exists. ${ }^{38}$ However, the fact that transformation is an evasive concept does not detract from its existence and centrality to our constitutional democracy.

A useful, albeit deficient, analogy for visualising the constitutional transformative project is the 'bridge'. The Epilogue (or Post-amble) of the interim Constitution first introduced the bridge analogy. The Epilogue provides that the interim Constitution was meant as:

a historic bridge between the past of a deeply divided society characterised by strife, conflict, untold suffering and injustice, and a future founded on the recognition of human rights, democracy and peaceful co-existence and development opportunities for all South Africans, irrespective of colour, race, class, belief or sex. ${ }^{39}$

Judicial Service Commission (n 23 above) para 44.

Currie \& de Waal (n 30 above) 13.

Soobramoney v Minister of Health, KwaZulu-Natal 19981 SA 765 (CC) para 8.

37 D Moseneke 'The Fourth Bram Fischer Memorial Lecture: Transformative adjudication' (2002) 18 South African Journal on Human Rights 315.

38 P Langa 'Transformative constitutionalism' (2007) 13 Stellenbosch Law Review 351.

39 Constitution of the Republic of South Africa 200 of 1993. 
This is fitting in a document that 'seeks to transform the status quo ante into a new order'. ${ }^{40}$ The Constitution was intended to be a:

decisive break from, and a ringing rejection of, that part of the past which is disgracefully racist, authoritarian, insular, and repressive ... and a vigorous identification of and commitment to a democratic, universalistic, caring and aspirationally egalitarian ethos. ${ }^{41}$

The temporal dimensions of the democratic transition, or passing over the bridge, are interesting. The past is well-defined. Standing on the bridge, it is the society behind us, marked by authoritarianism and human rights abuses. For Langa, the core idea of transformative constitutionalism is clear, 'we must change'. 42 The present and the future pose more of a challenge, less clear are the issues of what the society on the other side of the bridge looks like, and how we go about crossing the bridge to get there. ${ }^{43}$ In answering these questions Langa posits two ideas: firstly, that the new society is one based on substantive equality; and secondly, that transformative constitutionalism entails the transformation of legal culture. ${ }^{44}$

Klare considers substantive equality to be equality in 'lived, social and economic circumstances and opportunities needed to experience human self-realization'. ${ }^{45}$ Substantive equality is concerned with results and requires an examination of actual social and economic conditions in order to uphold the commitment to achieving equality. ${ }^{46}$ Substantive equality requires treating people who are similarly situated similarly and those who are dissimilarly situated differently. ${ }^{47}$ Klare states that the Constitution 'envisages equality across the existential space of the social world, not just within the legal process. ${ }^{48}$ This understanding entails that law cannot be neutral with respect to the distribution of social and economic power and opportunities for self-realisation. ${ }^{49}$

In President of the Republic of South Africa $v \mathrm{Hugo}^{50}$ it was stated that the achievement of equal treatment on the basis of equal worth and freedom was not possible by affording identical treatment in every situation. The test for constitutionality, as stated by Sachs $\mathrm{J}$ in Minister of Finance $v$ van Heerden, ${ }^{51}$ is not whether the measure treats everyone identically, but rather focuses on whether the

40 Du Plessis and Others v De Klerk and Another 19963 SA 850 para 157.

41 S v Makwanyane 19956 BCLR 665 (CC) para 262.

42 Langa (n 38 above) 352.

43 As above.

44 Langa (n 38 above) 352, 353.

45 K Klare 'Legal culture and transformative constitutionalism' (1998) 14 South African Journal on Human Rights fn 13.

46 Currie \& de Waal (n 30 above) 213.

47 Currie \& de Waal (n 30 above) 211.

48 Klare (n 45 above) 154.

49 As above.

$50 \quad 19974$ SA 1 (CC) para 41.

51200411 BCLR 1125 (CC) para 142. 
measure in practise advances or retards the equal enjoyment of rights and freedoms that are promised by the Constitution but have not yet already been achieved. Feminists are often credited with demonstrating that the application of formal equality has unjust results, and substantive equality should be sought. ${ }^{52}$

Section 1 of the Constitution provides that South Africa is 'one, sovereign, democratic state founded on '... [h] uman dignity, the achievement of equality and the advancement of human rights and freedoms'. ${ }^{53}$ Reference to the 'achievement' of equality is the first textual indicator that a substantive, as opposed to a formal, concept of equality is envisaged. Further textual indicators are contained in section 9 which provides for the right to equality. Section 9(2) provides that equality 'includes the full and equal enjoyment of all rights and freedoms' and enjoins the State to implement measures designed to advance persons, or categories of persons, disadvantaged by unfair discrimination. ${ }^{54}$ Section $9(3)$ and (4) prohibit unfair discrimination and provide for grounds upon which discrimination is presumed to be unfair according to section 9(5).

The Constitutional Court in Harksen $v$ Lane $\mathrm{NO}^{55}$ formulated a multi-stage test to determine whether unfair discrimination has occurred in terms of section 9. At the first stage, it must be considered whether there is mere differentiation. If a rational connection can be shown to exist between the differentiation and a legitimate governmental purpose, section $9(1)$ has not been

52 T Metz 'Is Legal Interpretation Subjective?' in D Bilchitz Jurisprudence in an African context (2017) 121.

53 Italics for my own emphasis. Section 1(a) of the Constitution of the Republic of South Africa 1996.

54 Italics for my own emphasis.

5519981 SA 300 (CC) para 50:

(a) Does the provision differentiate between people or categories of people? If so, does the differentiation bear a rational connection to a legitimate government purpose? If it does not, then there is a violation of section 8(1). Even if it does bear a rational connection, it might nevertheless amount to discrimination.

(b) Does the differentiation amount to unfair discrimination? This requires a twostage analysis:

(i) Firstly, does the differentiation amount to "discrimination"? If it is on a specified ground, then discrimination will have been established. If it is not on a specified ground, then whether or not there is discrimination will depend upon whether, objectively, the ground is based on attributes and characteristics which have the potential to impair the fundamental human dignity of persons as human beings or to affect them adversely in a comparably serious manner.

(ii) If the differentiation amounts to "discrimination", does it amount to "unfair discrimination"? If it has been found to have been on a specified ground, then unfairness will be presumed. If on an unspecified ground, unfairness will have to be established by the complainant. The test of unfairness focuses primarily on the impact of the discrimination on the complainant and others in his or her situation. (iii) If at the end of this stage of the enquiry, the differentiation is found not to be unfair, then there will be no violation of section $8(2)$.

(c) If the discrimination is found to be unfair then a determination will have to be made as to whether the provision can be justified under the limitations clause (section 33 of the Interim Constitution). 
infringed. ${ }^{56}$ The second stage of the test considers whether this differentiation amounts to unfair discrimination. To rebut the presumption imposed by section 9(5), it must be shown that this differentiation is not unfair discrimination. 57 What is apparent from section 9 as well as the substantive rationality requirements that the JSC's decisions must comply with, is that the Constitution attempts to create a culture of justification. ${ }^{58}$

A mere absence of manifest forms of discrimination, which might be challenged in terms of section 9 of the Constitution or in terms of the Promotion of Equality and Prevention of Unfair Discrimination Act (PEPUDA), ${ }^{59}$ should not be equated with the achievement of substantive equality or transformation. Returning to the bridge analogy, the Epilogue of the interim Constitution goes further to refer to a 'reconstruction of society'. 60 This reconstruction, according to Albertyn and Goldblatt, requires a 'redistribution of power and resources along egalitarian lines'.61 Furthermore, the achievement of equality within the transformation project requires the eradication of systemic forms of inequality and providing opportunities which allow people to develop to their full potential. ${ }^{62}$

In South African Police Service v Solidarity obo Barnard, the then Acting Chief Justice Moseneke, writing for the Constitutional Court, held that the Constitution's transformative mission hopes to reimagine power relations in South Africa. ${ }^{63}$ He stated further that it enjoins us to take active steps to achieve substantive equality. ${ }^{64}$ The measures which bring about transformation will necessarily adversely affect some people, particularly those from advantaged communities. ${ }^{65}$ In Soobramoney $v$ Minister of Health, KwaZuluNatal, ${ }^{66}$ the Constitutional Court stated:

We live in a society in which there are great disparities in wealth. Millions of people are living in deplorable conditions and in great poverty. There is a high level of unemployment, inadequate social security, and many do not have access to clean water or to adequate health services. These conditions already existed when the Constitution was adopted and a commitment to address them, and to transform our society into one in which there will be human dignity, freedom and

56 Harksen (n 55 above) paras 42, 53.

57 Prinsloo v Van der Linde and Another 19973 SA 1012 (CC) para 31.

58 Mureinik (n 33 above) 32

59 Act 4 of 2000.

60 Constitution of the Republic of South Africa 200 of 1993.

61 C Albertyn \& B Goldblatt 'Facing the Challenge of Transformation: Difficulties in the Development of an Indigenous Jurisprudence of Equality' (1998) 14 South African Journal on Human Rights 249.

62 As above.

6320146 SA 123 (CC) para 29.

64 As above.

65 Bato Star Fishing (Pty) Ltd v Minister of Environmental Affairs and Tourism and Others 20044 SA 490 (CC) para 74.

6619981 SA 765 (CC) para 8. 
equality, lies at the heart of our new constitutional order. For as long as these conditions continue to exist that aspiration will have a hollow ring.

For Langa, the 'levelling of the economic playing fields' is central to any concept of transformative constitutionalism. ${ }^{67}$ It goes beyond the fulfilment of socio-economic rights to require the provision of greater access to education and opportunities through mechanisms which include affirmative action measures. ${ }^{68}$ In light of this, Langa considers transformation to be a 'social and economic revolution'. ${ }^{6}$

Transformative constitutionalism goes further than this. Langa's second proposition is that it requires a transformation of legal culture. ${ }^{70}$ Under the Constitution, new conceptions of the judicial role and responsibility are contemplated. ${ }^{71}$ In keeping with this and the shift towards a culture of justification, Langa considers that under our transformative Constitution judges bear the responsibility to justify their decisions not only by reference to authority but by reference to ideas and values. ${ }^{72}$ This approach to adjudication requires acceptance of the political and ideological nature of law. Law does not operate in a vacuum. While politics and law are not the same thing, they are interconnected. ${ }^{73}$ Judges must acknowledge the effect of extra-legal factors, such as their moral preconceptions, on adjudication. ${ }^{74}$ In this regard, the Constitution imposes a shift from denying the influence of extra-legal factors, as was done by most judges under apartheid, to accepting and embracing the role that these factors play in decision-making. ${ }^{75}$ That law is ultimately political, and that extra-legal factors influence adjudication are central concepts in Critical Legal Studies (CLS) which are retained by CRT and critical legal feminism. ${ }^{76}$

\section{Introduction to feminist legal theory}

Feminism has a long and rich history which can roughly be divided into three (possibly four) so-called 'waves' which are defined not so much by time frames as by their preoccupations and methods. ${ }^{77}$ The first

67 Langa (n 38 above) 352.

68 As above.

69 As above.

70 Langa (n 38 above) 353.

71 Klare (n 45 above) 155.

72 Langa (n 38 above) 353.

73 As above.

74 As above.

75 As above.

76 J Modiri 'The grey line in-between the rainbow: $(\mathrm{Re})$ thinking and (re)talking Critical Race Theory in post-apartheid legal and social discourse' (2011) 26 Southern African Public Law 180.

77 Feminists such as Kira Cochrane and Prudence Chamberlain submit that a fourth wave arose in the early 2010s which is defined by the use of web-based tools, erosion of the gender binary, intersectionality and striving for justice. 
wave was concerned with the achievement of equal rights in a formal sense. Initially, these were civil liberties, followed by contract and property rights. ${ }^{78}$

'Personal is political' was the rallying slogan of the second wave, which was concerned with women's roles in the 'separate sphere'. The 'separate sphere', where women's world was domestic, is by definition incompatible with full participation in society. ${ }^{80}$ Taub and Schneider consider that the glorification of the 'women's destiny' softened the unfairness of being excluded from the legal profession. ${ }^{81}$

In the third wave, feminists are discussing the same issues of sex, money, reproduction and jobs as in the second wave, but are positing a more complex and nuanced concept of power. ${ }^{82}$ Power is considered to be a primarily productive force that shapes people by moulding their desires and self-concepts. ${ }^{83}$ Male power is pervasive, it is the foundation of institutions and the norm against which everyone is measured. ${ }^{84}$ In this third wave, questions of equality and gender are questions about the distribution of power, and at their roots are questions of hierarchy. ${ }^{85}$ It was around the end of the second wave and beginning of the third wave that critical legal feminist movements arose in the United States and Britain.

Before turning to critical legal feminisms in particular, it is useful to consider three main contributions that FLT made, generally speaking, to legal interpretation, according to Metz. ${ }^{86}$ Its first contribution was the problematisation of legal concepts such as the 'reasonableness' standard. ${ }^{87}$ While the 'man' aspect of the 'reasonable man' standard has been dropped in favour of 'person' FLT scholars argue that standards such as 'reasonableness' are inherently male. ${ }^{88} \mathrm{~A}$ woman will necessarily fall short when measured up to this standard. The second contribution of FLT is that it raised issues about the basic values which determine the distribution of benefits and burdens in society. ${ }^{89}$ Here it is argued by some that 'desert claims' or

78 C Huntington \& M Eichner 'Introduction, Special Issue: Feminist legal theory' (2016) 9 Studies in Law, Politics and Society 1.

79 As above.

80 N Taub \& EM Schneider 'Women's subordination and the role of law' (1993) in KD Weisberg (ed) Feminist Legal Theory: Foundation 14.

81 Taub \& Schneider (n 80 above) 15.

82 Huntington \& Eichner (n 78 above) 1.

83 Huntington \& Eichner (n 78 above) 5.

84 M Minow 'The Supreme Court 1986 term, Foreword: Justice engendered' in DK Weisberg (ed) Feminist Legal Theory: Foundation (1993) 306.

85 C Mackinnon 'Difference and dominance: On sex discrimination' in DK Weisberg (ed) Feminist Legal Theory: Foundation (1993) at 281.

86 Metz (n 52 above) 122 - 123.

87 Metz (n 52 above) 122.

88 As above.

89 As above. 
individual rights are a characteristically male way of thinking. ${ }^{90} \mathrm{I}$ will return to the issue of rights discourses later in this article.

The third contribution is the 'difference debate'. There are two overlapping discourses within this debate; the 'sameness versus difference' discourse; and 'difference versus dominance' discourse. ${ }^{91}$ The former is essentially concerned with the meaning of gender equality in the law. ${ }^{92}$ My understanding is that this debate is one which centres around whether formal equality (sameness) constitutes actual equality. Feminist scholars who equate sameness with equality are in the minority. Most insist that gender equality demands the recognition of and adaptation to gendered realities, issues such as reproduction and economic disadvantage vis-à-vis men. ${ }^{93}$

The latter discourse, 'difference versus dominance', consists of various explanations of the 'bad fit' between law and women's lived realities. ${ }^{94}$ My understanding of the debate is that what crucially differentiates the 'difference' from the 'dominance' group is the question of whether character differences between men and women are innate or acquired. 'Difference' or 'cultural' feminists consider these differences to be innate, and consequently, masculinist theories will inherently be biased against women. ${ }^{95}$ 'Dominance' or 'radical' feminists consider these differences to be forced upon women. ${ }^{96}$ According to Mackinnon, one such radical feminist, '[w]omen care because men have valued us according to the care we give them, women think in relationship terms because our existence is defined in relation to men." 97 Ultimately it was radical feminist legal scholars within the CLS framework who encouraged the rise of critical legal feminisms and CRT.

Critical legal feminisms and CRT arose within the CLS framework. CLS originated in the 1970s in the United States. The first Conference on CLS in 1977 was organised by scholars who had been students in the 1960 s and 1970s. This was a period of American history characterised by political and cultural challenges to authority. Continuing this tradition, CLS scholars set out to challenge prevailing ideas about the objectivity of the law. ${ }^{98}$ Within the CLS framework, the fields of CRT and FLT are characterised as 'outsider jurisprudence' as they are concerned with law's relationship with 'outsiders', namely women

90 As above.

91 JA Baer 'Feminist theory and the law' in RE Goodin (ed) The Oxford Handbook of Political Science (2011) 308.

92 Baer (n 91 above) 308.

93 As above.

94 As above.

95 As above.

96 As above.

97 MacKinnon (n 85 above) 281.

98 Berkman Klein Centre for Internet \& Society at Harvard University: The Bridge 'Critical Legal Studies Movement' https://cyber.harvard.edu/bridge/Critical Theory/critical2.htm (accessed 24 May 2020). 
and people of colour, particularly black people. ${ }^{99}$ Indeed, it was the 'outsider' status of feminist CLS scholars and CLS scholars of colour which gave rise to these fields.

In the mid to late 1980s the experience of marginalisation, tokenism and dismissal by the CLS 'malestream' laid the foundations for critical feminist legal movements. ${ }^{100}$ Female CLS scholars were 'ghettoised' at CLS conferences into sessions on feminist theory which male scholars did not attend. ${ }^{101}$ Frustrated, these feminist scholars eventually started forming their own conferences and levied challenges at CLS scholars for their silence on gender. This approximately marks the beginnings of the critical feminist legal movement.

Hunter considers there to be two fundamental ways in which critical legal feminism departs from 'orthodox' FLT. Firstly, it is committed to anti-essentialism; and secondly, it problematises feminist law reform efforts. ${ }^{102}$ Hunter conceptualises antiessentialism as entailing 'the acknowledgement that there is no singular Woman or 'women's experience' to provide a grounding for feminist theorizing or political action.'103 Two related strands of thought fed into this position; CRT and lesbian feminists problematised the mainstream liberal discourse's failure to consider black and lesbian women's experiences as the 'women's experience'. 104

Post-structuralists consider all subjects to be constructed in discourse rather than having rigid identities, consequently, they are all unstable and contingent. ${ }^{105}$ Critical legal feminism, unlike mainstream liberal feminism, embraced these discourses. An implication of this is that critical feminist scholars do not purport to present FLT as a 'coherent project'"106 Bottomley argues that feminism should be seen as 'a force, a movement of potentials rather than an identity', or as a field of activity within which scholars pursue divergent interests and needs, held together by the common recognition that they are challengers of the status quo, committed to making space for the many diverse voices within the field. ${ }^{107}$

99 S Gilreath 'Examining Critical Race Theory: Outsider jurisprudence and HIV/AIDS a perspective on desire and power' (2015) 33 Law \& Inequality: A Journal of Theory and Practice 373.

100 R Hunter 'Critical legal feminisms' in E Christodoulidis, R Dukes, M Goldoni (eds) Research handbook on critical legal theory (2019) 46.

101 As above.

102 Hunter (n 100 above) 48.

103 As above.

104 As above.

105 As above.

106 As above.

107 Anne Bottomley, 'Shock to thought: An encounter (of a third kind) with legal feminism' (2004) 12 Feminist Legal Studies 29 at 59 - 60. 
Another implication, and the second major divergence of critical legal feminisms from orthodox FLT, is that feminist legal reform efforts are problematised. ${ }^{108}$ If there is no one 'women's experience', on whose behalf do feminists argue? Anti-essentialism destabilised the feminist law reform project in the third wave, but the problematisation of law reform went further than anti-essentialism. 109 This will be explored in detail in the final section of this article.

\section{Introduction to Critical Race Theory}

In 1986 radical CLS feminist scholars, frustrated with the shortcomings of CLS, organised a conference to critique patriarchy within the CLS movement. ${ }^{110}$ They invited CLS scholars of colour to do the same concerning issues of race. This is considered by many to mark the 'birth' of CRT, at least in the Western context. ${ }^{111}$ The following year at the National CLS Conference, CRT scholars criticised CLS on its silence on race. This critique was not well received. ${ }^{112}$ Möschel and others suggest that CLS's incapacity to internalise or address CRT and FLT's critiques is what ultimately led to its demise. ${ }^{113}$ Instead, CRT and critical legal feminism thrived. In 1989 the first independent CRT workshop took place. Thereafter the field thrived independently. ${ }^{114}$

CLS and radical feminism provided the "intellectual and political openings' for CRT to develop as a field in its own right. ${ }^{115}$ CRT retained some of the central tenets of CLS, and these serve as a useful starting point for introducing CRT. According to Modiri the central thesis of CLS was retained by CRT and FLT, that is: law by nature is political and ideological and serves as a mechanism for preserving existing power relations. ${ }^{116}$ Here the role of extra-legal factors in adjudication and 'indeterminacy' is crucial.

Klare highlights the relationship between the issues of interpretative difficulty and indeterminacy on the one hand, and adjudication and the influence of extra-legal factors on the other. ${ }^{117}$ Klare explains that legal texts, particularly constitutions, do not 'selfgenerate' their meanings. Furthermore, in terms of linguistics and underlying norms, they are rife with ambiguities, unanswered

108 Hunter (n 100 above) 49.

109 As above.

110 M Möschel 'Critical Race Theory' in E Christodoulidis et al (eds) Research Handbook on Critical Legal Theory (2019) 63.

111 As above.

112 As above.

113 Möschel (n 110 above) 64.

114 Möschel (n 110 above) 65.

115 Möschel (n 110 above) 63.

116 Modiri (n 76 above) 180.

117 Klare (n 45 above) 159. 
questions and conflicts. ${ }^{118}$ In the face of legal indeterminacy, 'what's a decisionmaker to do? ... but to invoke sources of understanding and value external to the texts.' 119

Modiri considers that judges will always be confronted with multiple considerations and options, but their final decision will be the outcome of their political and ideological inclinations, rather than 'legal factors'. ${ }^{120}$ These external sources of understanding and value, according to CLS scholars, are political, particularly relating to class and ownership patterns in the economy. ${ }^{121}$ CLS scholars, strongly influenced by Marxism, were particularly concerned with class, but their critiques were limited regarding race and gender.

Turning now to CRT specifically, it should be noted that it is a broad and heterogeneous field, which is 'doctrinally and methodologically eclectic'. ${ }^{122}$ At the Second Workshop, scholars organised a discussion around a seven-point description of CRT's proposed main tenets. ${ }^{123}$ Möschel considers this description to essentially be stating that CRT seeks to challenge mainstream beliefs on racial injustice on three points. ${ }^{124}$

The first point is the issue of systemic anti-black racism; racism is not the malevolent actions of individuals but has social and institutional dimensions which routinely harm black people. ${ }^{125}$ In this regard racism is pervasive and it is imbued in the law. ${ }^{126}$ CRT attempts to understand people as concrete beings, who are measured up to the white, male norm of law; a shift away from universal rules, processes and categories. ${ }^{127}$ This is apparent in CRT methodology

118 As above.

119 As above.

120 Modiri (n 76 above) 181.

121 Metz (n 54 above) 111.

122 Möschel (n 110 above) 65.

123 From the notes of Professor Elizabeth H. Patterson, taken June 13, 1990, at the Second Critical Race Theory Workshop, held in Buffalo, New York. 'According to which CRT:

(i) holds that racism is endemic to, rather than a deviation from, American norms;

(ii) bears scepticism towards the dominant claims of meritocracy, neutrality, objectivity and color-blindness

(iii) challenges ahistoricism, and insists on a contextual and historical analysis of the law;

(iv) challenges the presumptive legitimacy of social institutions;

(v) insists on recognition of both the experiential knowledge and critical consciousness of people of color in understanding law and society;

(vi) is interdisciplinary and eclectic (drawing upon, inter alia, liberalism, poststructuralism, feminism, Marxism, critical legal theory, post-modernism, pragmatism), with the claim that the intersection of race and the law overruns disciplinary boundaries;

(vii) and works toward the liberation of people of color as it embraces the larger project of liberating oppressed people'.

124 Möschel (n 110 above) 65.

125 As above; see also Metz (n 54 above) 115.

$126 \mathrm{~N}$ Naffine Law and the sexes: Explorations in feminist jurisprudence (1990) 8.

127 Modiri (n 76 above) 180. 
which is very personal. In providing a counterhegemonic account of the law, minorities' experiences may be heard through a legal narrative. ${ }^{128}$ This is why, Möschel notes, CRT writings often incorporate personal stories. ${ }^{129}$ This relates to an aspect of the proposition that law is imbued with white culture and values. Naffine explains that at one level it posits the claim that law is made by white people and entrenches their position and power. ${ }^{130}$ At a deeper and more personal level, it claims that law is conceived through the white eye, and represents the white perspective, failing to recognise the views and experiences of black people. ${ }^{131}$

The second point is the popular, so-called 'colour-blind' narrative, in other words, the misconception that 'blindness to race will eliminate racism'. ${ }^{132}$ 'Colour-blindness', combined with the denial of racial hierarchy and culpability for a racist past, is considered counterproductive. ${ }^{133}$ Such a combination only serves to entrench racism. ${ }^{134}$ In the South African context, Modiri is critical of the 'grand narrative' of a nation built on 'non-racialism'. ${ }^{135}$ Calls for colour-blind politics are misplaced in a country where de facto apartheid remains, meaning that the same macro-structure of apartheid persists as wealth, knowledge and power rest with the white minority. ${ }^{136}$ To this end, Modiri argues that South Africa's majority black government is merely a 'token achievement'. ${ }^{137}$

The third point is that racism cannot be fought in a vacuum. Attention must be paid to other forms of oppression and injustice, including sexism, homophobia and economic exploitation. ${ }^{138}$ In the South African context Modiri considers poverty to be an important form of oppression, and emphasises that we live in a country in which de facto apartheid persists, as the apartheid macrostructure of 'imperialist white supremacist capitalist patriarchy' remains although under a different legal and political arrangement. ${ }^{139}$ 'White supremacy' does not refer to extremist hate groups but a political,

128 Möschel (n 110 above) 65

129 As above.

130 Naffine (n 126 above) 8.

131 As above.

132 Möschel (n 110 above) 65.

133 Ansell 'Casting a blind eye: The ironic consequences of colour-blindness in South Africa and the United States' (2006) 32 Critical Sociology 340.

134 Metz (n 52 above) 116.

135 Modiri (n 76 above) 183.

136 As above.

137 As above.

138 Möschel (n 110 above) 66.

139 JSM Modiri 'Law's Poverty' (2015) 18 Potchefstroom Electronic Law Journal 228-229. 
legal, economic and cultural system which maintains white control and black oppression in its mode as usual. ${ }^{140}$

\section{Critical Race Theory and Feminist Legal Theory perspectives on rights and transformation}

CLS scholars are generally dismissive of rights, in particular the right to equality. Some argue that appeals to ideas about equality mask real inequality in relationships. ${ }^{141}$ According to Williams, CLS's blanket critique of rights is not only ahistorical but also reflects white left privilege. ${ }^{142}$ Further, Williams states that the argument that rights are inconsequential or harmful 'trivialises this aspect of black experience specifically'. ${ }^{143}$ She suggests that white CLS scholars downplay the importance of rights because they have taken it for granted that society recognises their humanity. ${ }^{144}$ There are very mixed views on rights in CRT and FLT, however, they are generally regarded as being more sympathetic to normative categories of rights than CLS. ${ }^{145}$

The history of feminism, according to some, corresponds with the history of the concept of equality. ${ }^{146}$ Smart takes this further by stating that feminism also corresponds with the idea that equal opportunities can be achieved through the law in the form of rights. ${ }^{147}$ Smart notes that as liberalism gained ascendancy, the desirability of equality of opportunity was inextricably linked to the idea that it could be achieved through the law. Thus, law was conceptualised as a potentially neutral arbiter and means of protecting the oppressed, as opposed to being implicated in that very oppression. 148

Rights appear to be an attractive tool for advancing the interests of oppressed groups for several reasons. Firstly, interests can be advanced through the 'political language' of rights, to formulate an issue as a rights issue is to make the claim popular, as it enters into

140 JSM Modiri 'The colour of law, power and knowledge: Introducing Critical Race Theory in (post-) apartheid South Africa' (2012) 28 South African Journal on Human Rights 406.

141 Metz (n 52 above) 112.

142 PJ Williams 'The alchemy of rights and law' (1991) in S Hassim 'Decolonising equality: The radical roots of the Gender Equality Clause in the South African Constitution' (2018) 34 South African Journal on Human Rights 347.

143 Williams (n 142 above) 152.

144 Williams (n 142 above) 347.

145 Metz (n 52 above).

146 See for example; J Mitchell 'Women and equality' in A Phillips Feminism and equality (1987).

147 C Smart Feminism and the power of the law (1989) 139.

148 As above. 
an accessible 'linguistic currency'. ${ }^{149}$ Secondly, a claim to rights is loaded, Smart notes that 'it is almost as hard to be against rights as it is to be against virtue.' 150 Thirdly, rights are depicted as a means of protecting the weak from the strong, especially vertically. ${ }^{151}$

Smart accepts that rights amount to legal and political power resources, but proceeds to make what I think is a profound point: 'the value of such resources seems to be ascertainable more in terms of losses if such rights diminish, than in terms of gains if such rights are sustained. ${ }^{152}$ I understand this to mean that the availability of a right is felt less than its unavailability. This is because there are systemic aspects to non-fulfilment of a right, its mere availability does not mean it is taken advantage of. To use loose economic terms, the utility (enjoyment) gained when a right is made available is less than the utility lost when it is denied. I understand the implication of this is that because oppressed groups suffer deeply when the right is denied, there is a false expectation that life will become that much better when that right is made available. Without systemic change, the results of availing that right may be disappointing.

Madlingozi critiques human rights on the basis of humanity. Central to the concept of social justice is the idea that all humans are able to pursue happiness and derive a fair share of the collective good by virtue of being human, and all humans have equal worth. ${ }^{153}$ Madlingozi posits the question; 'what kind of 'human' is being invoked here?' ${ }^{154}$ Recalling the notion of a non-European 'Other' in colonial history, he points out that the 'human' in human rights has never had a shared, objective normative understanding. ${ }^{155}$ Madlingozi considers that if human rights are extended from those advantaged groups who arrogated the status of humanity to those 'Others' the 'coloniality of being' is perpetuated in the absence of revolutionary processes of self-reclamation put forward by Black Consciousness activists in the past. ${ }^{156}$ Madlingozi advances what he admits is a controversial argument, that the 'fetishisation' of human rights both conceals and entrenches teleological whiteness. ${ }^{157}$ It masks the true struggle, which is the struggle for humanity, or 'quest towards true humanisation'. ${ }^{158}$ White supremacy has co-opted the discourse of

149 Smart (n 147 above) 143.

150 As above.

151 As above.

152 As above.

$153 \mathrm{~T}$ Madlingozi 'Social justice in a time of neoapartheid constitutionalism: Critiquing the anti-black economy of recognition, incorporation and distribution' (2017) 28 Stellenbosch Law Review 136.

154 Madlingozi (n 153 above) 136.

155 As above.

156 As above.

157 Madlingozi (n 153 above) 137.

158 As above. 
social justice and its fetishisation of human rights. ${ }^{159}$ Madlingozi contends that calls for a supreme constitution with a bill of rights largely came from the ranks of the historically privileged. ${ }^{160}$ It was seen as a means of blocking rather than promoting change which was achievable through the de facto constitutional concretization of historical injustice. ${ }^{161}$

Hassim, on the other hand, argues that the claim that rights were imposed on South Africans or are an innately Western concept inextricable from the condition of coloniality is ahistorical. ${ }^{162}$ Rather, rights discourses have a rich history in South Africa, particularly within feminist movements, as the right to equality is a product of a century-long struggle by black women. ${ }^{163}$ Hassim draws attention to the two Women's Charters; the first, 'What Women Demand' was adopted by the Federation of South African Women in 1954. ${ }^{164}$ The second, 'Women's Charter for Effective Equality' was adopted by the Women's National Coalition in $1994 .{ }^{165}$ Hassim considers that these Charters extended the right to equality in three respects; firstly, they included the private sphere in the domain of rights. ${ }^{166}$ Secondly, they broadened the scope of human rights to include sexual and reproductive autonomy. ${ }^{167}$ Finally, they established the rights of women to full participation and representation in political institutions. ${ }^{168}$ These dimensions stemmed from changes women desired in their actual lives. ${ }^{169}$ These documents articulate the idea of political community differently than the Freedom Charter in that they include women as full members of the nation. ${ }^{170}$ According to Hassim, this exposed the false universalism of Marxism and nationalism, which assumed that women would automatically be accommodated as members of the nation or class. ${ }^{171}$ The idea that women are full members of the nation is now entrenched in the Constitution, however, Hassim contends that

without these struggles, there is little doubt that 'we, the people' would not be a formulation that addressed the particular tensions between citizens of different gender, or the hierarchies of power that sustained a multiplicity of patriarchies. ${ }^{172}$

159 Madlingozi (n 153 above) 139.

160 Madlingozi (n 153 above) 141.

161 A Sachs Protecting human rights in the new South Africa (1990) 12.

162 Williams (n 142 above) 343.

163 As above.

164 Hassim (n 142 above) 343

165 Hassim (n 142 above) 350.

166 As above.

167 Hassim (n 142 above) 350.

168 As above.

169 Hassim (n 142 above) 350.

170 Hassim (n 142 above) 351.

171 As above.

172 Hassim (n 142 above) 351. 
Despite this major contribution, these Charters are rarely referred to as being the roots of the Constitution, reference is made to the Freedom Charter instead. ${ }^{173}$

Returning to the issue of rights, Smart argues that there are four major problems with rights and relying on them to further women's interests. The first issue is that rights oversimplify complex power relations, the result being that acquisition of rights may convey that the power imbalance has been remedied. ${ }^{174}$ In fact, the right merely draws the state's attention to an issue, but it does not necessarily resolve the problem. ${ }^{175}$ The second problem is that resort to rights can effectively be countered by resort to competing rights. ${ }^{176}$ This is especially clear in the criminal justice system, where the rights of the victim may be side-lined in favour of the rights of the accused. ${ }^{177}$ In the same vein, the third problem is that while rights are formulated to deal with a social wrong, they are focused on the individual who must prove a violation of her rights. ${ }^{178}$ The last issue is the issue of appropriation; rights formulated to protect the 'weak against the strong' may be appropriated by the more powerful. ${ }^{179}$

From the above discussion, it is apparent that there exists a range of views on the usefulness of rights and transformative constitutionalism, which is based on rights. It appears that CRT scholars, in general, are sceptical of transformative constitutionalism and the promise of human rights given that South Africa remains in a state of de facto, or neo- apartheid. ${ }^{180}$ According to Modiri, there are two foundational principles of CRT's approach to transformation. First is the issue of the centrality of racism; racism is not a distortion of reality, but a pervasive, normalised and ingrained feature of our social order. 181 Second, 'white supremacy' does not refer to extremist hate groups but a political, legal, economic and cultural system which maintains white control and black oppression in its mode as usual. ${ }^{182}$

Modiri considers that presently 'black people control white supremacy', a majority black government is a 'token achievement' in a country trapped in the same macrostructure of apartheid. ${ }^{183}$ While people are incorporated under the guise of transformation or racial

173 As above.

174 Smart (n 147 above) 144.

175 As above.

176 Smart (n 147 above) 145.

177 Smart gives the example of refusal to alter the procedures of evidence in child sexual abuse cases because, in spite of the child's right not to be abused, the accused has a right to a particular form of trial.

178 Smart (n 147 above) 145.

179 As above.

180 Modiri (n 76 above) 183; Madlingozi (n 153 above) 125

181 Modiri (n 140 above) 406.

182 As above.

183 Modiri (n 76 above) 183. 
integration, we continue the same system of white supremacy. ${ }^{184} \mathrm{He}$ goes as far as to say that constitutional rights and protections extolled by constitutional lawyers, judges and academics are a 'vicious rumour' to most black people who remain trapped in the structural violence of poverty and other violations of their purported socioeconomic rights. ${ }^{185}$ He states that the co-option of black people in white-dominated institutions makes them feel that their interests are being served, while patterns of oppression remain undisrupted. ${ }^{186}$ Modiri argues further that we need to shift away from thinking that apartheid is a legal mistake which can be fixed by new laws and black judges, we need to recognise that racism is a socially engineered, pervasive power structure that requires radical transformation. ${ }^{187}$

Like Modiri, Madlingozi argues that the promised 'decisive break from the past' did not happen, and states that in fact, the Constitution is transforming society in ways that do not amount to a fundamental rupture from society's configuration under de jure apartheid. ${ }^{188}$ Furthermore 'social justice', which he states is the mainframe of transformative constitutionalism, is complicit in the continuation of this societal structure. ${ }^{189}$ In the constitutional negotiations, the democratisation paradigm triumphed over the decolonisation paradigm, and with that triumph, any hopes of real, societal transformation were quashed. ${ }^{190}$

\section{Abstention and the notion of refusal}

Shifting the focus of this article to the transformation of the judiciary, there are arguments in favour of transforming the racial and gender identity of the institution. It is hardly disputed that proportional representation of black judges enhances the legitimacy of the judiciary, and this public perception is crucial to the functioning of the legal system. ${ }^{191}$ This is because people believe, correctly according to CRT and FLT, that judges do not apply the law impartially. Their dispensation of justice is influenced by their perspectives. This is where shared perspectives play a role in influencing the public perception of the judiciary. ${ }^{192}$

184 Modiri (n 76 above) 188.

185 Modiri (n 76 above) 195.

186 Modiri (n 76 above) 188

187 As above.

188 Madlingozi (n 153 above) 125.

189 As above.

190 Madlingozi (n 153 above) 143.

191 L Fuentes-Rohwer and KR Johnson 'A principled approach to the quest for racial diversity on the judiciary' Articles by Maurer Faculty, Indiana University (2004) 28.

192 Klare (n 45 above) 159. 
The notion of shared vulnerability explains why the average person before a court and the judicial officer, who are worlds apart in terms of class, education and socio-economic standing, may share similar perspectives. Butler's conception of power as defined by race and gender is a primary productive white, patriarchal and capitalist force which shapes the lives, desires and perspectives of those moulded by it is relevant here. ${ }^{193}$ The perspectives of the oppressed group can only be truly acknowledged when heard by other members of that same group. ${ }^{194}$

Van Marle and Brand argue that transformation is distinct from evolution, evolution occurs when the institution changes on its own terms without changing its identity. ${ }^{195}$ The identity of the institution will represent patterns of power, especially along racial and gender lines. Transformation is radical enough that the identity of the institution changes. ${ }^{196}$ Transformation entails risk and problematising those existing positions of power, it requires acknowledgement of the subjective nature of existing standards and conceptions of merit. ${ }^{197}$

Modiri notes that radical reformation of societal structures and a revisiting of law and its limits are linked to the ethics of refusal. ${ }^{198}$ Abstention from voting in the presence of appropriately qualified white male candidates is a radical act in support of transformation. Abstention from voting is an act of refusal, it is a rejection of pressure to make choices the actors fundamentally disagree with. ${ }^{199}$ There is nothing in the Constitution that prohibits members of the JSC from abstaining from voting, and I would argue there should never be impediments to the right to refuse, it is a crucial expression of agency. The adoption of refusal signals a revolt against existing forms of power along racial and gender lines. ${ }^{200}$ Refusal is a means of disrupting present systems and discourses within law and politics. ${ }^{201}$ In the post-apartheid context, it involves rethinking prevalent ideas on law, transformation and democracy. ${ }^{202}$ Refusal takes the 'risk of thought' without the burdens of proving immediate success. ${ }^{203}$

193 Huntington \& Eichner (n 78 above) 5.

194 SM Smith 'Diversifying the judiciary: The influence of gender and race of judging' (1994) 28 University of Richmond Law Review 198.

195 K Van Marle \& D Brand 'Ten thoughts on transformation' in Heyns and Visser Transformation and Faculty of Law of the University of Pretoria (2007) 56.

196 Van Marle \& Brand (n 195 above) 55

197 Van Marle \& Brand (n 195 above) 56.

198 JSM Modiri 'Race and rac(ial)ism, the politics of peace and friendship' (2010) 43 Pretoria Students Law Review 52.

199 Y Jooste 'What would my mother say? Refusal, forgiveness and the subjectivity of South African women' (2013) 46 De Jure 741.

200 Modiri (n 76 above) 184.

201 K Van Marle 'Laughter, refusal, friendship: Thoughts on a "jurisprudence of generosity"' (2007) Stellenbosch Law Review 196.

202 Jooste (n 199 above) 744.

203 As above. 
Unawareness of the white male norm in law and its role in oppressing black people and women is fostered by the shared belief of legal institutions and actors that process is what matters. ${ }^{204}$ Process is a mechanism which can serve to replicate existing power structures, it may pressure the actor to bend to the calculations of political and practical effectiveness. ${ }^{205}$ Refusal in the face of pressure imposed by process is an intellectual act of judgment, it decides firmly what is just and what is not. In this way, it is a counterhegemonic action which challenges law in its mode of business as usual and is inextricably tied to transformation. 206

If vacancies are not held open for appropriately qualified black and female candidates, those positions will continue to replicate themselves, there will be no radical transformation, but incremental change swallowed up by the systematic favouring of white legal professionals. ${ }^{207}$

\section{Conclusion}

It is clear that there are divergent streams of thought in FLT and CRT, especially relating to the issues of human rights and transformation. Perhaps it is best then, as Bottomley suggests, to think of FLT, and indeed CRT, as a 'force'. This article aimed to explore the various perspectives on the right to equality and transformation in our constitutional dispensation, which are issues relating to transformation in the judiciary. In doing so it explained the standards against which the JSC's decisions are measured and the historical background to its creation. An attempt was made to introduce the fields of CRT and FLT in general, before focusing on the issue of transformation and the right to equality in South Africa. I have argued that the abstention from making judicial appointments is justified as an act of revolt, tied to the notion of radical transformation. Perhaps it is in the spirit of these issues that I am left with more questions than answers.

204 AC Scales 'The emergence of feminist jurisprudence: An essay' in DK Weisberg Feminist Legal Theory Foundation (1993) 45

205 P Hanafin 'The writer's refusal and the law's malady' (2004) 31 Journal of the Learning Sciences 10.

206 Jooste (n 199 above) 743.

207 Van Marle

\& Brand (n 195 above) 56. 